\title{
Efficiency and Effectiveness of Alternative Dispute Resolution Schemes Towards the Promotion of Access to Justice in Bangladesh
}

\author{
Mohammad Saidul Islam*
}

\begin{abstract}
In recent years in Bangladesh there has been renewed emphasis on the Alternative Dispute Resolution schemes as a means to avoid the use of contested hearings in the formal litigation and to ensure the most fundamental right of access to justice for all in an easy way. These Alternative Dispute Resolution (ADR) modalities are considered as less likely to fuel the parental conflicts, more likely to induce the parties to resolve their conflicts in an amicable manner preserving the future relationship between the parties and reducing cost, delay and loss of energy to a significant extent. Following the considerable advantages of ADR almost every county of the world has introduced ADR system in its justice delivery system which has paved the way to the promotion of access to justice indiscriminately for all. This paper is an attempt to provide a comprehensive idea about obstacles in the way of access to justice in our legal system and by analyzing the different mechanisms of $A D R$ and court and non-court based practices of those modalities under different legislations of Bangladesh, to show the fairness, efficiency and effectiveness of ADR towards the promotion of access to justice and to provide some recommendations for the complete success of ADR towards the effective, non-discriminative, speedy and easy access to justice for all either rich or poor, literate or illiterate, male or female and elite or lower class.
\end{abstract}

\section{Introduction}

In any state, access to justice is considered a most coveted aspiration and is regarded as vital component of human rights because injustice

* Lecturer, Department of Law, International Islamic University Chittagong. 
anywhere is a threat to justice everywhere. Every man born with some human rights, some of them have been guaranteed in the chapter of fundamental rights in the constitutions of the most of the countries of the world. Bangladesh constitution guarantees to every citizen equality before law and ensures the right to enjoy the protection of law and to be treated in accordance with law. ${ }^{1}$ These rights have also been guaranteed in different international and regional documents .The Universal Declaration of Human Rights 1948 says everyone is entitled to all the rights and freedoms which have been set forth in this declaration without distinction of any kind, such as race, color, sex etc. ${ }^{2}$ The African Charter on Human and Peoples Rights provides that every individual shall be equal in the eye of law. ${ }^{3}$ The responsibility to ensure these rights and to deliver justice to the common people has been vested on the legal institutions including courts. But due to some reasons, access to justice to the vast majority of people has become a hollow promise guaranteed under the constitution. The reasons are inordinate delay, repetition, backlogging of cases, high cost, complex procedural rules, limited opportunity or incentives for consensual settlements etc. ${ }^{4}$ Our legal system theoretically ensures access to justice for each and every citizen of the country but in practice the door of justice is not open for disadvantaged segment of the society. ${ }^{5}$ In most of the cases access to justice is only available to the resourceful person and powerful elite since in order to have access to justice one must have the means which includes money. ${ }^{6}$ This scenario is common in civil justice delivery system where the parties fight in a 'do or die' manner with no or little prospect of any consensual settlement. So we have the only choice the "Alternative Dispute Resolution" which can easily and quickly ensure access to justice. At present ADR is seen by many as an important part of the countries' judicial framework, particularly in so far as the civil justice delivery system is concerned. ADR is a range of processes which without following adversarial and formal judicial process assists the disputants to solve their dispute in amicable way with harmony. ExChief justice Mustafa Kamal described ADR as "a non -formal settlement of legal and judicial disputes as a means of disposing of cases quickly and inexpensively" The European Commission, in its green paper on ADR stated:

ADRs offer a solution to a problem of access to justice faced by the citizens in many countries due to three factors: the volume of disputes brought before the court is increasing, the proceedings are becoming more lengthy and costs incurred by such proceedings are increasing. And quantity, complexity and technical obscurity of litigation also help make access to justice more difficult. As ADR is voluntary and consensual system it helps the parties to tell their own story and give 
the parties opportunities to participate fully in the process.

\section{Access to Justice}

Access to justice is granted as a fundamental right almost in every democratic country of the world. Bangladesh Constitution confirms that the Republic shall be a democracy in which fundamental human rights and freedom and the respect of the dignity shall be granted and equality before law, equal protection of law are ensured and the right to fair trail is protected. The concept of access to justice includes the whole range of laws, procedures and institutional arrangement through which justice can be delivered to the people in efficient and effective manner and it denotes the instrumentalities by which citizens can approach the courts, lawyers, legislatures, judges and administrative agencies for both substantive and procedural justice. ${ }^{8}$ In 1994, the commonwealth Government appointed the access to justice advisory committee which stated that access to justice involves-

1. Equality of access to legal service;

2. National equity; and

3. Equality before law. ${ }^{9}$

Washington State Access to Justice Board states that access to justice includes meaningful opportunities, directly or through other persons: (i) to assert a claim or defense and to create, enforce, modify or discharge a legal obligation in any forum; (ii) to acquire the procedural or other information necessary; (iii) to participate in the conduct of proceedings as witness or juror; and (iv) to acquire information about the activities of the courts or other dispute resolution bodies. ${ }^{10}$ Access to justice connotes that the justice must be equal both for rich and poor and every one must have right to get justice through easy, quick and effective way but our legal system failed to ensure justice for all equally due to some reasons.

\section{Efficiency and effectiveness of ADR towards Access to Justice}

Development of ADR in different countries of the world, especially in developing countries is a step towards the proper administration of civil justice for all equally. It has successfully opened the door of justice equally for rich and poor which the ordinary legal system has failed to do. Through ADR the parties can reach to a harmonious settlement of the dispute which is opposed to the win-lose outcome of the legalistic and formalistic approach of litigation. ${ }^{11}$ Usually the winlose situation becomes a rigorous obstacle in the way of future relationship between the parties. As it sequels win-win situation which not only settles the dispute but also brings peace and healing that 
preserve the future relationship between the parties. Avoiding all kinds of legal procedural complexities, technical legal principles it follows the process which the parties and their appointed mediator think best for the settlement of their issue. In ADR the parties select and control the process of it for smooth, correct, effective and efficacious remedy and they are under the liberty to appoint any expert in the subject matter of the dispute. ${ }^{12}$ Through ADR, avoiding formal process of the court, it is not impossible to settle more than one suit in a single sitting which not only saves the time and energy of the litigants but reduces the cost to a significant extent. Apart from ensuring these benefits it can provide social and psychological benefits to the parties. So a vast number of disputes are settled through ADR which enormously reduces the tremendous pressure on the current suits in the ordinary courts. One important positive side of ADR is absolute maintaining of privacy because privacy is a key value which underpins human dignity and it is a basic human right and the reasonable expectation of every person. ${ }^{13}$ Once a mediation settlement is reached and a decree is passed the case is finally disposed of. Unlike a trial there is no possibility of a dispute, settled through mediation, being revived. ${ }^{14}$ Another important advantage of ADR is the liberty of the parties to withdraw the suit at any time, in any stage of the suit, from the formal court and to send for the settlement through ADR and the resolution through formal ADR bears the strength of a judicial decree that is expected to contribute greatly towards the level of confidence and popularity of the mechanism amongst litigants. ${ }^{15}$ The informality of ADR and NGO promoted dispute resolution initiatives, particularly mediation, paved the way for the marginalized men and women and grassroots members of the community to participate in local adjudication. ${ }^{16}$ For these advantages of ADR, judicial mediation and arbitration have been introduced in many parts of the world and in many legislations of Bangladesh. Most of the family court cases in Bangladesh involve financial claims. Statistics show that the total realization of money through execution of decree in suits disposed of by trial is far below than the total realization of money in dispute settled through mediation. From 1985 to 2000 total money realized in connection with family suits in three courts is Tk.61, 99,759/50 whereas the total realization through mediation since the introduction of mediation in the same courts from June 2000 up to $16^{\text {th }}$ May 2001 i.e. in twelve months is Tk.50, 94,501/00. ${ }^{17}$

\section{Barriers in the way of Access to Justice}

There are some obstacles in the way of access to justice which can be described as follows: 
1. Delay: The age old adage states "justice delayed justice denied". Delay is the main obstacle to the dispensation of justice. Delay in our judiciary has reached at a point where it is the main factor of injustice, violator of human rights. One or two years necessary for the disposal of a suit may swell up to 12-15 years or even more. By the time the judgment is pronounced the need for it in many respects may have been over. ${ }^{18}$ For illustration, in a suit for the restitution of conjugal right by husband, the date on which the judgment was pronounced by the court the woman was married and a child was born to her. ${ }^{19}$ These are many cases of the same kind where delay in disposal creates many social human problems. The law commission ${ }^{20}$ of Bangladesh points out six reasons for the delay in the disposal of a suit i.e. abundant number of cases, procedural complexities etc.

2. Prohibitive cost of litigation: The principal object of the legal system is to ensure equal justice for all. We cannot conceive of justice that is not fair and equal, which is given to one and denied to another. Justice should be done alike to rich and poor. Where discrimination is done among the rich and the poor to deliver justice, which is not justice but injustice. It was inserted in the charter of liberties of Henry 11 and Magna Carta, where it is inscribed.

"To no man will we deny, to no man will we delay, justice or right" ${ }^{21}$ But equal justice is not possible in the ordinary court of law which involves huge amount of money .i.e. the court fee, lawyers` fee, money to collect certified copies of the judgment, decree or order and other incidental costs. So it becomes impossible to ensure equal access to justice.

3. Procedural complexities: The procedural complexities are the main interruptions to provide justice to the people. Justice Krishna Iyer comments about the court system of India-

Watching the dilatory complexities of our forensic procedures, the meaningless waste of judicial time and energy from the trail courts to the supreme courts and the easy possibility of economy of time and money, one wonders why we hesitate to change. ${ }^{22}$

4. Backlogging of cases: The judicial system of Bangladesh is jammed by a huge backlog of suits or cases .The backlog of cases causes wearing delays in the adjudicating process which is, as described by professor M. Shah Alam ${ }^{23}$ "eating Bangladesh judiciary" while delay in the judicial process causes backlog, mounting backlog puts a tremendous load on the present cases. ${ }^{24}$

5. Corruption in judiciary: Corruption is the vital cause for non- 
functioning the judiciary properly. It has destroyed our judicial system.

6. Want of efficient, independent and dutiful judges and lawyers: To maintain access to justice properly, it is sine qua non that the judges and lawyers must be honest, efficient, independent and dutiful to their duties. If the judges and the lawyers of a country are not honest, efficient, independent and dutiful, the people of that country may be deprived of the benefits of even good laws of the country. ${ }^{25}$ One author correctly stated: "truism that the quality of justice depends more on the quality of persons who administer the law than on the content of the law they administer,"26

7. Lawyers economic interest in the litigation.

8. Non- availability of legal aid.

9. Non- existence of separate court for the separate subject matter.

10. Centralization of judiciary.

Bangladesh legal study group (BLSG) identified the following problems in our legal system-

1. Lack of accountability

2. Absence of discipline and fragmentation in the litigation and

3. The absence of versatile alternatives to full trial $^{27}$

\section{Possible way outs to overcome these problems}

Bangladesh is not only a country which is buffeted by these problems, even the developed countries such as the United States of America, the United Kingdom, India and other countries of the world. To solve these problems USA and following its inspiration many countries including Australia, Germany, Hong Kong, New Zealand and United Kingdom have been using over the last 25 years, alternative way which is popularly known as $\mathrm{ADR}^{28}$

The abovementioned problems are faced by the courts in our country, especially in civil justice system, but the existing legal system is unable to solve them. So initiative was taken in 1996 by Mr. Justice Mustafa kamal the then chief justice of Bangladesh to commence reforms in our legal system. Since then a co-operation has been built up with the Institute for the Study and Development of Legal Systems (ISDLS) of USA to benefit our system with the American experience in this field and to work out an appropriate mechanism for resolving problems faced by our civil courts. 
Subsequently, in January 2000, a trip by Judge Clifford Wallace in Dhaka finalized the selection of a five member Bangladesh legal study group under the leadership of justice Mustafa kamal. ${ }^{29}$ The BLSG made a report; one of the recommendations made in the report is to initiate immediately a pilot project on mediation. On the basis of this recommendation, BLSG decided to introduce mediation in family courts and started a pilot project. ${ }^{30}$ Under this project the Family Court acquired a great triumph which induced the lawmakers to insert this system in different laws in Bangladesh.

\section{Different types of ADR in legal framework of Bangladesh:}

ADR is a means of resolving dispute which is an alternative to going to the court. It may be any one of the two forms either determinative or elective, all mechanisms of ADR fall within these two forms.

Determinative ADR is any non court process which will determine the outcome of the dispute. It involves a third party, whether an arbitrator or an adjudicator or an expert acting as a determinative capacity. Elective ADR is that which facilitates discussion, which usually turns into negotiations which does not produce any judgment or finding which is binding on the parties. ${ }^{31}$ The various modalities of ADR, Conciliation, Mediation, Settlement Conference, Arbitration, Minitrial, Negotiation, Appellate ADR, Village court, Board of Conciliation and Traditional Salish $^{32}$ which are practiced in Bangladesh can be classified under the following three categories -

1. Formal/judicial ADR

2. Quasi-formal/statutory ADR

3. Informal /Non-formal ADR

\section{Formal /judicial ADR}

This form of ADR indicates those processes of dispute resolution which have been enumerated in the statutes and conducted either by the court or by the third person upon the reference of the court. ADR processes in the formal ways are conducted by the following Statutes of Bangladesh.

1. The Code of Civil Procedure (Amendment) Act, 2003: Mediation and arbitration have been inserted in section 89A and 89B of the Code of Civil Procedure, for all civil suits except suits under the Artha Rin Adalat Ain 2003, through the Code of Civil Procedure (Amendment) Act 2003. Section 89A stipulates that at any stage, after filing the written statement, if all the contesting parties are present in person or by their pleaders apply to the court showing their willingness to settle 
the dispute through mediation, the court may, adjourning the hearing, mediate in order to settle the dispute or refer the dispute to the engaged pleaders of the parties or parties, where no pleader has been engaged or refer to the mediator from the panel as prepared by the district judge in consultation with the president of the District Bar Association. The mediator of the panel may be a pleader or retired judge or person known to be trained in the art of dispute resolution or such other person or persons as may be deemed to be appropriate for this purpose but any person holding office of profits in the service of the republic shall not be qualified for being mediator of the panel. It is also stipulated that a mediator shall not act as mediator between the parties if he has been engaged by either of the parties as a pleader in any suit. ${ }^{33}$ Mediation has been defined under section $89 \mathrm{~A}$ as flexible, Informal, Non-binding, confidential, non-adversarial and consensual dispute resolution in which the mediator shall facilitate compromise of the dispute without direction or dictating the terms of such compromise. ${ }^{34}$ It is the discretionary power of the court that after the filing of the written statement, it may either mediate or refer the dispute to the pleaders or the parties or the mediator for settlement. Thus, unlike the USA where pre-trial mediation is compulsory but the judicial mediation in civil suits in Bangladesh is consensual and voluntary. So the provisions regarding mediation remained mostly unpractised for making it voluntary for the judges to take step for mediation, lack of motivation of the concerned judges, ignorance of the parties and unwillingness of the lawyers.

When reference under s/s (i) is made to the pleaders of the parties, they shall in consultation with the clients appoint another pleader or a retired judge or a mediator from the panel or any other person whom they seem to be suitable. Here the parties have the option to appoint more than one mediator. ${ }^{35}$ The procedure of mediation and the fees of the mediator shall be determined by the parties and pleaders, not by the court. But when the mediation is conducted by the court then the procedure of mediation will be determined by the court and no fee will be charged from the parties. ${ }^{36}$

A time-frame has been set out for speedy disposal of mediation. Within 10 days from the reference, the parties shall inform in writing to the court that whether they have agreed to settle the dispute through mediation or not and within 60 days from the day on which the court is so informed the mediation shall be completed unless the time is further extended for 30 days for the joined application of the parties ${ }^{37}$. The mediator shall submit a report regarding the result of the mediation proceeding. If any settlement is possible, an agreement incorporating 
the terms of settlement shall be reduced to writing signed by the parties, pleaders and mediator and the court shall pass an order or a decree following the report of the mediator. Where the court itself mediates the dispute, it shall also pass an order or decree in the similar manner. And the court shall issue a certificate directing refund of the court fees paid by the parties. And no appeal or revision shall lie against the order or decree passed by the court on the basis of settlement through mediation ${ }^{38}$. Where compromise is not possible, the court shall proceed with the hearing of the suit from the stage at which the suit stood before the decision to mediate. Where the court itself tried to settle the dispute through mediation and failed, in that instance, the suit will be heard by another competent court. ${ }^{39}$ This rule is inserted to avoid the biasness of the judges. On the other hand, failure to settle the dispute shall not limit the option of the parties regarding withdrawal, adjustment and compromise of the suit under Order23 of the C.P.C $1908 .^{40}$ This provision has made open other methods of alternative settlement.

It is always open for the parties to withdraw the suit for arbitration either they have taken the help of mediation or not. Section 89B provides that if the parties, at any stage of the proceeding, are willing to settle the dispute through arbitration may apply before the court for the withdrawal of the suit and refer to the arbitrator and it will be settled by the arbitrator in accordance with the Arbitration Act 2001. ${ }^{41}$

Following the massive success of mediation at the trial stage, the mediation proceeding has been incorporated at the appellate stage by section 89C of the Code of Civil Procedure through the Code of Civil Procedure (Amendment) Act 2006. For mediation in appellate stage the procedure described in section $89 \mathrm{~A}$ will be followed.

\section{The Family Courts Ordinance 1985}

The most important provisions have been inserted in the Family Courts Ordinance 1985 for the conciliation between the parties at pre-trial stage and trial stage of suits concerning divorce, dower, maintenance, restitution of conjugal life and custody of children. A attempt to settle the dispute through alternative process is compulsory for the judges. Section 10 says after the filing of the written statement, the court shall examine the plaint, written statement and the documents filed by the parties and if it deems fit, hear the parties. It shall ascertain points at issue and attempt to reach a compromise between the parties. If no compromise or conciliation is possible at this pre-trial stage, the court shall proceed for the trial of the dispute. Section 13 provides that again the Family Court, after the close of all evidences but before the 
pronouncement of the judgment, shall make an effort to effect compromise or reconciliation between the parties. These good provisions on mediation have been inserted in family matters just to preserve the relationship and peace between the parties.

These healthy provisions on mediation remained unpracticed since the enactment of the Ordinance due to lack of motivation of the concerned judges and due to using the adversarial system the judges presiding over Family Courts were completely ignorant about mediation. ${ }^{43}$ To activate ADR provisions in the Family Court a pilot project was taken in 2000 in the Family Courts of Dhaka. Following the massive success of these courts it was extended to all the Family Courts in Bangladesh and different forms of ADR have been introduced by amending many laws of the country. In mediation in Family Courts the parties can directly participate in the settlement process and they are allowed to voice their position in joint session because settlement opportunities are discussed privately. The parties are helped to realize the result of the suit if they proceed with the litigation. The most positive result of it is to provide opportunities to the women, who are unwilling to expose themselves to public eye going to the court, to directly participate in the dispute resolution process and voice her grievance without being condemned by critical eyes because all the activities performed on mediation in family courts are quite confidential. ${ }^{44}$

\section{Artha Rin Adalat Ain, 2003}

Under sections 21 and 22 of the Artha Rin Adalat Ain 2003, two modes of the ADR, settlement conference and arbitration, have been introduced in the commercial dispute. Section 21 defines the Settlement Conference as a conference comprising the parties, their lawyers and their representatives and presided over by the judge of the Artha Rin Adalat for disposing of the suit in an informal, non-binding, confidential and non-adversarial manner on the basis of mutual cooperation and understanding of all concerned." 45 Section 21 deals with the details procedure of the Settlement Conference and section 22 provides for the arbitration of the commercial dispute. After the filing of written statement the court may, keeping pending all subsequent proceeding refer the suit to the lawyers of the parties or where no lawyers have been engaged, to the parties themselves. But where the parties agree to try and settle the dispute through arbitration, the court is bound to refer the dispute for arbitration. Inserting the ADR system in commercial dispute certainly improves the investment in this field.

\section{Quasi-formal ADR}

Where the application, jurisdictions and modes of ADR are regulated 
by statute but conducted by a non-judicial body that is Quasi-formal ADR. Quasi-formal ADR mechanisms in different legislations of Bangladesh are -

\section{The Muslim Family Laws Ordinance 1961}

To make the divorce effective ${ }^{46}$ the husband after pronouncement of talaq shall send a notice as soon as possible to the chairman and a copy of it will also be sent to the wife. From the date of receiving the notice of talaq within 30 days the chairman shall constitute an arbitration council which shall take all necessary steps for reconciliation between the parties. A talaq will not be effective until the expiration of ninety days from the day on which the notice was delivered to the chairman or if the wife is pregnant after the pregnancy ends, whichever period is longer. In what form either Ahsan or Hasan or Bidaat form, the talaq is pronounced it will be deemed as a single talaq in ahsan form, so husband can revoke the talaq anytime either expressly or impliedly I.e. to kiss her or consummate with her or touch her etc or after ninety days by remarry if it is not for third time. The failure of husband to give notice to the chairman is deemed to be revocation of talaq. ${ }^{47}$ In Abdul Aziz vs. Rezia Khatoon, it was held the non-compliance with section 7(1) makes talaq legally ineffective. ${ }^{48}$ Where wife exercise the delegated right that is talaq-e-tawfez, she must also follow the procedure of section $7 .^{49}$ This healthy provision on conciliation has been incorporated in the Muslim Family Laws Ordinance 1961 to prevent the separation between husband and wife which is the result of pronouncement of talaq that usually occurs on sudden anger of husband. For taking additional wife $\mathrm{e}^{50}$ or to get adequate or equitable maintenance, ${ }^{51}$ the party must apply before the chairman who will constitute the arbitration council which will decide these matters in informal and amicable way without following the procedure of courts.

\section{The Conciliation of Dispute (Municipal areas) Board Act, 2004}

The Municipal Board consisting of five members chaired by the chairman of the municipal area has exclusive jurisdiction without some exceptions in cases mentioned in the Schedules as per Section 4(1). ${ }^{52}$ In the proceeding of the Municipal Board, CPC, Cr. P.C and the Evidence Act will not be applied ${ }^{53}$ and no party can engage any advocate in such proceeding ${ }^{54}$ The Act is entirely on conciliation and within its framework that the decision of the conciliation board is mandatory, but right to appeal is open.

\section{The Arbitration Act, 2001}

The Arbitration Act 2001 is applicable in respect of recognition and enforcement of foreign arbitral awards and in relation to a dispute 
arising out of the arbitration agreement entered into before or after the enforcement of the Act. ${ }^{55}$ Under the Arbitration Act 2001, arbitration is mandatory if any dispute falls within the ambit of the $\mathrm{Act}^{56}$ or if any civil suit, at any stage of it, is withdrawn on the application of the parties for arbitration then it will be settled in accordance with the Arbitration Act 2001. ${ }^{57}$

\section{The Village Court Act, 2006}

If any dispute either civil or criminal comes within the ambit of The Village Court Act 2006, it shall be dealt with by the Village Court consisting of five members including the chairman who will preside over the Village Court and each party shall select two members of which one must be a member of Union parishad. The procedures enumerated in the Evidence Act, the C.P.C and the Cr.P.C shall not be applicable in village court and no party has right to engage any lawyer in proceeding of such court.

\section{The Labour Code, 2006}

Chapter 14, section 210(1) to (19) describes the procedures of mediation, conciliation and arbitration.

\section{ADR Mechanism in Criminal Justice System}

In criminal justice system the ADR system has not been properly developed in our country. A list of petty offences which are compoundable described in section 345 of the Cr.P.C $1898 .{ }^{58}$

\section{Informal /Non- formal ADR}

Disputes are also resolved through alternative methods at the community level in both civil and criminal matters by non-judicial body, which may be described as informal ADR. Different NGOs (i.e. Madaripur Legal Aid Association (MLAA), Bangladesh Legal Aid and Services Trust (BLAST), Ain O Shalish Kendra (ASK) and Banchte Shekha (BS) etc) are involved in the dispute resolutions at the community level.

\section{Other Legislative Provisions relating to ADR:}

1. Sec. 28 of The Contract Act 1872, regarding arbitration.

2. Sec. 21 of The Specific Relief Act 1877, regarding arbitration.

3. Sec. 76 of The Bank Companies Act 1991.

4. Sec. 6 of The Parbatto Chattagran Birod Nispoti Commission Ain 2001

The insertion of the provisions of ADR in many laws of the country has opened the door of access to justice for the vast majority of the 
people. Under these statutes, disputes, through ADR, are settled within a very short time which reduces the cost of the parties. So justice through ADR can be ensured for all whether they are poor or rich.

\section{Success of ADR in Bangladesh}

After the insertion of ADR mechanisms in the different existing laws, a great achievement in the disposal of the suits has been acquired by ADR which can be perceived from the following pictures.

1. Since the activation of ADR in the family courts the average rate of substantive disposal by compromise through mediation has gone up to $60 \%$ compared to contested decree.

2. Under the pilot project in 13 districts total number of disposal of cases by way of mediation from 2000 to 2004 is 2418 and during this time through these courts total amount of realization is Tk.77770455.

3. Under section 89A of C.P.C total 12402 cases were disposed through mediation from July 2003 to June 2006.

4. Through the Artha Rin Adalat Ain total 24945 cases were solved through ADR from May 2003 to February 2006 across the country. $^{59}$

\section{Recommendations towards an effective ADR system:}

No doubt, ADR is efficient and effective towards the promotion of access to justice, yet there are some weaknesses which are the impediments to the effective ADR system which are (i) lack of knowledge and awareness among the people; (ii) inadequate roles played by the legal professionals;(iii) absence of appropriate and institutional framework; (iv) absence of trained lawyers and judges regarding mediation;(v) negative impression among the lawyers regarding ADR; (vi) non-application of ADR in old cases under section 89A;(vii) mediation and arbitration are optional under C.P.C;(viii) in criminal cases non-inclusion of certain petty offences in the compounding provisions of the Cr.P.C;(ix) want of separate ADR legislation;(x) deep-rooted faith and mind sets in the traditional systems; and (xi) the community based ADR mechanism is weakened by endemic corruption, partisan, conflicting local politics, illiteracy etc. These impediments can be removed by the implementation of the following recommendations which will enhance the access to justice through the effective ADR mechanisms:

1. Various actors like the GOB ministries, the NGOs, the local 
government bodies, the media and other civil society can play an important role in promoting awareness, popularity and effectiveness of the ADR mechanism in Bangladesh.

2. The judiciary both civil and criminal may play an important role towards the effectiveness of the ADR.

3. For the performance of the activities of ADR a separate institutional framework should be developed and equipped with proper decorations.

4. Separate skilled and trained mediators should be appointed only for performing mediations.

5. Separate code can be enacted for the successful ADR in Bangladesh.

6. Establishment of separate mediation courts, for both civil and criminal matters, with jurisdictions is essential for the success of ADR.

7. Family Court Model of Pre-trial hearing should be inserted in all civil suits.

8. The limitation imposed by section 23 of the Artha Rin Adalat Ain 2003 must be removed.

9. To acquire success through ADR the attitude of lawyers and judges must be changed.

10. Legal aid must be given to the poor litigants. For this purpose the Aingoto Sohayota Prodan Ain 2000 must be amended.

11. Establishment of a statutory body entrusted with the responsibilities of policy formulating, planning, promoting and monitoring the overall ADR system of the country.

12. Considering the nature of the dispute the fee of the mediators, arbitrators and conciliator should be determined by the statute.

13. It is bare necessary to review sec. 345 of Cr.P.C1898 and the list of compounding offences must be enlarged.

14. In criminal cases ADR is applied only in some C.R cases, so provisions should be made so that the G.R cases can also be resolved through ADR.

15. The mediation courts should be established in every Upazilal Thana. 


\section{Conclusion}

Alternative Dispute Resolution mechanisms are believed to be a consensual approach to the settlement of dispute not following the intractable formalities of the adversarial trial system. It is described as informal, confidential, expeditious, effective, mutual participatory, cost and emotion effective, promoter of peace and social harmony by removal of enmities and contributor to a breakthrough in prevailing crisis of backlogging of cases. The Alternative disputes resolution schemes are not a new phenomenon in our society but never widely used for formal civil process. What is new is the extensive promotion and proliferation of ADR models and its increased uses. The traditional shalish system was practised in the community level for the settlement of disputes during Muslim period in this sub continent and the Panchayat model was introduced in 1870 during the British period to resolve minor disputes within the local area and are practiced all over Bangladesh till now and the NGOs assisted mediation especially in family related matters, is a popular method of dispute resolution to the marginalized people of the country due to their enthusiastic approach to the settlement. Though the traditional shalish has a potential utilities, considerable advantages of the parties and effectiveness, it is now increasingly losing credibility due to imposing the arbitrary decision on the reluctant disputants by the powerful personnel of the village. But court annexed ADR schemes are the very recent development in Bangladesh since 2000 and achieved a tremendous success to settle the disputes in alternative way with the intervention of the court. It has created a great expectations and hopes to the litigant public because when a dispute is settled expeditiously with the saving of cost and time of the parties in an amicable way under the supervision of the court it is likely to ensure integrity, impartiality and authenticity of the mechanisms. The incorporation of compulsory ADR mechanism in Family Court has effectively opened the multidoor house of delivering justice to the people. The very recent development of ADR in civil suits both at trial and appellate stages and in commercial disputes reflect a shift from traditional litigation to ADR for enhancing access to justice. These newly inserted provisions of ADR in different legislations of Bangladesh have created a window of opportunity of access to justice for all especially for the poor or disadvantaged groups of people who cannot go to the court due to their financial constraint or if they go to the court, they cannot equally move against the strong opponent by engaging a powerful lawyer for their financial limitation. Almost invariably, as found from this article that ADR has a very significant role towards the enhancement of access to justice avoiding all kinds of procedural and other complexities. ADR in compare to the regular courts keeps efficacious and effective role 
for the promotion of access to justice by ensuring consensual settlement, actual participation of the parties, reducing cost and saving the time and energy of the parties. Realizing the great success of ADR, almost all countries of the world have inserted the provisions of ADR in their civil and criminal justice system. In Bangladesh after the insertion of ADR in the Family Court, the Civil Court and Artha Rin Adalat it has acquired a great success in this field. But for getting satisfactory success of ADR it requires a motivation of the concerned judges, training program of the judges, lawyers and mediators, should take awareness building program for the general people, needs adequate institutional and policy support, to take appropriate legal reform and in particular the judges should take an activist stand to fully utilize the court annexed ADR in Bangladesh.

\section{Works Cited:}

1. The Constitution of the Peoples Republic of Bangladesh (adopted $4^{\text {th }}$ November 1972, entered into force 16 December 1972) art. 27, 28 and 31

2. The Universal Declaration of Human Rights (adopted 10 December 1948 UNGA Res 217 A (!!!) UDHR art 2

3. The African Charter on Human and Peoples Rights (adopted 26 june1981, entered into force October 1986) art 3

4. ALAM, M. SHAH. (2001) “Alternative Dispute Resolution by early judicial intervention: A possible way out of delay and backlog in our judiciary. Manual for clinical legal education, $\mathrm{p}-54$

5. NASER, MOSTAFA MAHMUD,(2006) The Role of clinical legal education in increasing access to justice: The context of Bangladesh, commonwealth legal education conference, $\mathrm{p}-54$

6. Ibid, $\mathrm{p}-54$

7. The Daily Star, (2007) April, 29, p-2

8. Dr. Faruque-Al-Abdullah (2006) "Promoting access to justice through Judicial Mediation." The Bangladesh Experience, Commonwealth Legal Education Conference. P-46

9. Access to Justice and Legal Needs Project, Background Paper, Understanding access to justice and legal needs, The report access to justice Roundtable Proceeding of a Workshop, July 2002, organized by Law and Justice Foundation of NSW, Australia.

10. www.wsba.org/public.atjtechnologyprinciples. last visited on 5th April, 2011

11. BHATT, Justice JITENDRA N. (2002) "A Round Table Justice through Lok Adalat (Peoples Court) A vibrant-ADR- in India"(2002) 1SCC(Jour)11

12. RAO. P.C. Alternative to Litigation in India, edited P.C. RAO and WILLIAM SEFFIELD, Universal Law Publishing Co. Pvt. Ltd. New Delhi, at P-24 
13. AHMAD ISHRAT AZIM and KARIM Md. ERSHADUL. (2006) Principles of civil litigation: Bangladesh perspective: first edition, Law Lyceum, P-222

14. Supra 12, P-25

15. Sattar, Dr. Rana,(2006) Existing ADR framework and practices in Bangladesh: A Rapid Assessment-CIDA BLRP-B/MLJPA-Gob/P-54

16. Ibid, $\mathrm{p}-54$

17. Hasan, Mr. Justice K.M. (2005) Alternative Dispute Resolution, Bangladesh Institute of law and International Affairs (BILIA) edited by Wali-ur- Rahman and Mohammad Shahabuddin, at P-133

18. Supra $-4, \mathrm{p}-54$

19. Rahman, Dr. Rafiqur, (1986) Civil Litigation in Bangladesh: first edition. p-159

20. The law commission of Bangladesh, established under the AIN COMMISSION AIN 1996 (Act No. xix of 1996)

21. Magna Carta, Paragraph-14

22. Justice Iyer, Krishna,V.R: Law, lawyers and justice, B.R. Publishing Corporation Delhi, P-134

23. Alam, M. Shah, A Possible way out of Backlog in our judiciary, The Daily Star, Dhaka, 16 April 2000.

24. Mahbub, SK. Golam,(2005) Alternative Dispute Resolution in Commercial Dispute, $1^{\text {st }}$ edition, Kathal bagan, Dhaka, P-13

25. Haque, Kazi, Ebadul, (2003) Administration of justice in Bangladesh Asiatic Society of Bangladesh, P-252.

26. Even, Haynes,(1944) the selection and tenure of judges (Newark)P-5

27. Hasan, Mr. Justice K.M. (2005) Alternative Dispute Resolution, Bangladesh Institute of law and International Affairs (BILIA) edited by Wali-ur- Rahman and Mohammad Shahabuddin, at P-125

28. Supra-12, P-24

29. Supra-27

30. Ibid

31. Broadbent Nigel, (2009) Alternative Dispute Resolution, Cambridge journals, Legal information management 9 (2009) the British and Irish Association of Law Liberations, p-195

32. Halim Md.Abdul (2010) ADR in Bangladesh: Issues and Challenges. Ist edition, CCB Foundation, p-33

33. The Code of Civil Procedure, 1908(as amended in 2003 by Act 8 of 2003), Section 89-A (10)

34. The Code of Civil Procedure, 1908(as amended in 2003 by Act 8 of 2003) Explanation-I, Section 89-A

35. Ibid, section 89-A (2)

36. Ibid, section 89-A (3)

37. Ibid, section 89-A (4) 
38. Ibid, section 89-A (12)

39. Ibid, section 89-A (9)

40. Ibid, section 89-A (13)

41. The Code of Civil Procedure, 1908(as amended in 2003 by Act 8 of 2003), Section 89-B

42. The Code of Civil Procedure, 1908 (as amended in 2006 by Act 8 of 2006) section $89-\mathrm{c}$

43. supra-27, $\mathrm{p}-127$

44. Ibid, $\mathrm{p}-128$

45. The Artha Rin Adalat Ain, 2003 (Act No.8 of 2003) Explanation 1, Section 21

46. The Muslim Family Law Ordinance 1961 (Ordinance No. 8 of 1961), section 7

47. Haq Dr. Naima, Divorce Conciliation: Without the intervention of the Court and built-in Conciliation in Family Court Proceedings, The Dhaka University Studies, Part-F, Vol. xii (i): June 2001, p-8

48. 21 DLR (1969) 733

49. Supra-46, section-8

50. Supra-46, section-6

51. Ibid, section 9

52. The Conciliation of Disputes (Municipal Area) Board Act, 2004 (Act No. 12 of 2004) sec, 7

53. Ibid, sec 13

54. Ibid, sec, 14

55. The Arbitration Act, 2001(Act No.1 of 2001) Section 3

56. Ibid, section 39

57. The Code of Civil Procedure, 1908(as amended in 2003 by Act 4 of 2003) sec, 89B

58. Section 345 of The Code of Criminal Procedure 1898

59. Source: Ministry of Law Justice and Parliamentary Affairs. 